\title{
iaspm@journal
}

ISSN 2079-3871

\section{REVIEW I Queerness in Heavy Metal Music: Metal Bent}

\author{
Amber R. Clifford-Napoleone \\ London and New York: Routledge, 2015 \\ ISBN: 9780815365587 (PB)

\section{Liam Maloy} \\ University of Nottingham \\ liam.maloy@nottingham.ac.uk
}

Heavy metal is queer. But rather than manifesting in the exceptional out gay artist or the rare LGBT-themed song, this book asserts that queerness is an essential quality of the music, performances, fans, fashions, and other elements that comprise the ecology of heavy metal. As Clifford-Napoleone notes, heavy metal was forged in the melting pot of "BDSM style and symbolism, leather subcultural cues, overt visual and lyrical images of 'abnormal' sexual behaviour, and performers who defy heteronormative cultural norms of appearance and behaviour" (11). This engaging monograph arrives on a recent wave of scholarly interest in all things heavy metal including the establishment of the International Society for Metal Music Studies and the Metal Music Studies journal, conferences such as Heavy Metal and Gender (hosted at University of Music, Cologne in October 2009), and recent scholarly publications to include Global Metal Music and Culture: Current Directions in Metal Studies (edited by Brown, Spracklen, Khan-Harris and Scott 2016), Heavy Metal Studies and Popular Culture (edited by Riches, Snell, Bardine and Gardenour Walter 2016), and Heavy Metal Music and the Communal Experience (Scott 2016).

This publication also responds to a flush of recent texts exploring issues of queerness in popular music. These include Jodie Taylor's Playing It Queer (2012) which surveys queer local punk and riot grrl bands; Doris Leibetseder's Queer Tracks (2012) which covers mostly female musicians (such as Peaches, Lady Gaga, Grace Jones, Annie Lennox, Madonna) who subvert gender norms; Stan Hawkins' pop-oriented Queerness in Pop Music (2015); and the genre-straddling edited collection Queering the Popular Pitch (Whiteley and Rycenga 2006). Yet whilst some of these and other authors have discussed issues of gender and divergent sexuality in a range of genres including punk, hard rock, and heavy metal (for example Jarman-Ivens 2007; Leonard 2007; and Whiteley 1997), this book is long overdue in placing the queerscape of heavy metal front and centre. 
The book's extensive ethnographic research of LGBTQ heavy metal fans is underpinned by relevant queer theory and the author's thorough social and historical contextualization of queer texts and artists. The fans' interpretations of the music, lyrics, and on-stage performances, and their discussions of homophobia and effeminophobia within the scene are perhaps Clifford-Napoleone's main contribution to the field. The author's assertion of heavy metal's inherent queerness is in many ways oppositional to many more-established heavy metal scholars. Clifford-Napoleone's aim is to queer metal music studies by wrestling back academic assertions of a primarily heteronormative culture that perpetuates images of hypermasculinity and hyperfemininity. As the author notes throughout, previous studies have positioned out queer performers such as Judas Priest's Rob Halford as exceptions to metal music's patriarchal discourse (Walser 1993: 109). This publication takes issue with the masculinist thrust and the "static nature" of metal and hard rock scholarship to date (11). Whilst many authors assume an audience of heterosexist readers and draw on tired notions of metal's "masculinist code" (Weinstein 1991: 13), Clifford-Napoleone argues that a diversity of fluid gender and sexual identities define and continue to redefine heavy metal music and culture.

In the largely theoretical introduction and first chapter the author unpacks the terms "queer" and "heavy metal" whilst defining the dual role of the queer fan of heavy metal through the use of queerscape theory. Much attention is paid to asserting the influence of queer culture on mainstream heavy metal. In doing so, Clifford-Napoleone offers a divergent take on established notions of metal's sexual exclusivity in which female forms are "exscripted" either through elimination or by adaption to meet male heterosexist stereotypes (Walser 1991: 13). The book rejects claims by Whiteley that "rock's function is to confer masculinity" (13) and takes issue with Frith and McRobbie's description of rock as "male camaraderie" with an "absence of women" (13), as well as Reynolds and Press's denial of the queer readings offered by Suzi Quatro, Joan Jett and L7 (14). The author criticizes scholars who assume that queerness in heavy metal is an atypical aside in a fundamentally homophobic scene (15). This book instead builds on Davies' assertion that "All rock and roll is homosocial" (2001: 301-319), whilst the ethnographic sections align with Taylor's fan-focussed Playing It Queer (2012) and the more recent Heavy Metal Music and the Communal Experience by Scott (2016).

The second chapter describes how black leather, studs, and other BDSM and gay subcultural fashion came to define the look of heavy metal from the late 1970s onwards. Clifford-Napoleone traces the style from German pilots, American motorcycle gangs (and their significant gay membership), Marlon Brando, Eddie Cochran, Gene Vincent, the Hamburg-era Beatles, Elvis in 1968 through to Rob Halford in 1978. The overtly-gay leatherman/woman style became "straightened" in the queerscape of heavy metal, "a place of queer connections, rendered unintelligible to the heteronormative world" (38).

The third and fifth chapters affirm how queer heavy metal fan communities are both productive and consumptive. Through discursive activity on social media and the production of so-called slash fiction, wikis, and blogs, queer fans carve out the "desire-zones" (20) that define the queerscape and allow the divergence of sexualities and genders to thrive within heavy metal. However, within this largely nonconformist culture, issues of effeminophobia (negative attitudes against the "frilly and feminine" (136)) are still rife with sexist attitudes perpetuated even within queer heavy metal communities (135-137). The interviews paint a vivid picture of how queer heavy metal fans of all genders adopt masculine looks in order to pass as straight and avoid abuse in clubs and mosh pits. 
This extensive surveying and interviewing of self-selecting queer heavy metal fans also informs the fourth chapter which discusses issues of gender and sexuality in heavy metal performers. Unsurprisingly perhaps, the scene's most celebrated gay performer Rob Halford is the subject of eight pages (79-87) whilst other out gay metallers such as Gaahl and Otep Shamaya are discussed with referenced to a range of theoretical positions and through auto-ethnography. Considerations of female masculinity centre around Joan Jett ("the queer queen of cock rock" (95)) and Otep, whilst Laura Jane Grace of Against Me!, Mina Caputo of Life of Agony, Marissa Martinez of Cretin, and guitarist Annah Moore of Ignitor are examined in the brief section on trans performers (101-103). The final chapter uses case studies such as Judas Priest's "Eat me alive" and Rammstein's video for "Mein Teil" to explore issues of corporeality and "bodies as sites of consumption" (110). Through the examination of responses from fans, the PMRC, journalists, and scholars to artistic representations of real-life incidents of sexualised cannibalism and vorarephilia, Clifford-Napoleone concludes by suggesting that heavy metal's queerscape is in a position to embrace the "abject cultural features that even the queer mainstream seeks to avoid" (135). Whilst heavy metal's horrific depictions of transgressive sexuality may not have ubiquitous appeal even within queer metal communities, the genre's inherent queerness and constant exploration of gender, sexuality, and notions of taste and acceptability offer something of the potentiality that José Muñoz describes in his introduction to Cruising Utopia (2009). In sentiments echoed throughout this book, Muñoz describes a queerness that "propels us onwards, beyond romances of the negative" and a longing for a better world "promised by queerness in the realm of the aesthetic" (2009: 1). Rooted in queer theory, heavy metal scholarship, and ethnography, Clifford-Napoleone's timely text greatly enhances our understanding of the aesthetics and practices of the current queerscape of heavy metal.

\section{References}

Brown, A., Spracklen, K., Khan-Harris, K. and Scott, N. Eds., 2016. Global Metal Music and Culture: Current Directions in Metal Studies. New York: Routledge.

Davies, H., 2001. All Rock and Roll is Homosocial: The Representation of Women in the British Rock Press. Popular Music 20 (3): 301-319.

Frith, S. and McRobbie, A. 1978. Rock and Sexuality. In S. Frith and A. Goodwin Eds. On Record: Pop, Rock and the Written Word. New York: Pantheon, 1990: 371-390.

Hawkins, S. 2015. Queerness in Pop Music: Aesthetics, Gender Norms and Temporality. London: Routledge.

Jarman-Ivens, F. Ed., 2007. Oh Boy!: Masculinities and Popular Music. London: Routledge.

Leibetseder, D. 2012. Queer Tracks. Surrey, England: Ashgate Publishing Limited.

Leonard, M. 2007. Gender in the Music Industry: Rock, Discourse and Girl Power. London: Ashgate.

Muñoz, J. 2009. Cruising Utopia. New York: New York University Press.

Reynolds, S. and Press, J. 1995. The Sex Revolts: Gender, Rebellion and Rock'n'Roll. Cambridge, MA: Harvard University Press.

Riches, G., Snell, D., Bardine, B. and Gardenour Walter, B., Eds. 2016. Heavy Metal Studies and Popular Culture. London: Palgrave Macmillan. 
Scott, N., 2016. Heavy Metal Music and the Communal Experience. New York: Lexington Books.

Taylor, J., 2012. Playing it Queer: Popular Music, Identity and Queer-World Making. Oxford: Peter Lang.

Walser, R., 1993. Running with the Devil: Power, Gender, and Madness in Heavy Metal Music. Middletown, CT, USA: Wesleyan.

Weinstein, D., 1991. Heavy Metal: The Music and its Culture. New York: DaCapo Press.

Whiteley, S., 1997. Sexing the Groove: Popular Music and Gender. London: Routledge.

Whiteley, S. and Rycenga, J., Eds. 2006. Queering the Popular Pitch. London: Routledge. 